\title{
D-3 DEFORMATIONAL STYLES OF THE CENTRAL AND EASTERN MEDITERRANEAN RIDGE
}

J. MASCLE', C.HUGUEN', J. BENKHELIL ${ }^{2}$, A. VOLKONSKAIA ${ }^{3}$, J. WOODSIDE ${ }^{4}$ AND THE SCIENTIFIC PARTY

'Géosciences Azur, UMR 6526, PO Box 48, Port de la Darse, 06235 Villefranche-Sur-Mer, France 2Perpignan University ${ }^{3}$ Moscow State University

‘Amsterdam Free University

\section{Summary}

Details of the sea floor and of deformational styles of large portions of the central and eastern Mediterranean Ridge (MR) are revealed in recent $100 \%$ coverage swath bathymetry, acoustic imagery, together with continuous seismic profiling. The MR is a wide accretionnary wedge that results from convergence and ongoing incipient collision between Europe, Africa and the Anatolia-Aegea microplate, in Eastern Mediterranean.

In February 1998 we conducted a geophysical survey to investigate two areas of the sea floor of the Central and Eastern MR.The bathymetry and backscatter images were mapped using a Simrad EM12D multibeam system The seismic reflection system was comprised of two GI 75 airguns and a six channels streamer.

General Morphology : The surveyed areas show morphological provinces characterized by distinct bathymetric features and trends. From South to North, we recognize: The MR foreland which includes the African continental slope and, eastward, the deep Herodotus abyssal plain. Disconnected from the Lybian slope by narrow deeps, or direcly facing the southern abysal plain, the MR front is characterized either as an almost linear and relatively steep escarpment, as a series of small crescent-like scarps (west of $24^{\circ}$ east) or as a series of large scale bathymetric undulations. The sea floor of the MR can been subdivided into several domains. We observe first an outer region characterized by important variabilities. East of $24^{\circ} \mathrm{E}$, the sea floor comprises numerous elongated (a few $\mathrm{km}$ to $20 \mathrm{~km}$ ) northeast-southwest tending features. This domain widens from a few $\mathrm{km}$, at $24^{\circ} \mathrm{E}$, to about $100 \mathrm{~km}$ in the eastern area, where the sea floor surface forms irregular, and aligned reliefs and depressions. Further north, the MR exhibits some remarkable characteristics. To the east, it characterizes by an almost flat, surface. Towards west, particularly west of $24^{\circ} \mathrm{E}$, the sea floor displays a complex morphology in a shallower area. We observe elongated and curved features aligned in a northsouth trend and small cones along a northwest-southeast oriented belt. Most of the bathymetric features appear to reflect trend variations detected along the southern MR front and along the African slope. North of this region, the MR countains abundant sub-circular features, particularly in the western domain. These are concentrated into regions which correlate with mud volcano fields (Camerlenghi et al., 1992 ; Limonov et al., 1999 ; Huguen, 1998). En echelon features form north-south trending lineaments; one is seen approximately along $24^{\circ} \mathrm{E}$, between the western MR area and the deeper eastern domain. Further North the MR is characterized either by large-scale crescent-like reliefs, expressed in a series of elongated basins and bordering highs, or is in almost direct contact with a series of seamounts that bounds the deep continental margin south-east of Crete.

The northern margins of this region are bounded by slightly curved and gentle slope segments facing a series of disconnected deep troughs the Pliny trench system. 
Acoustic Imagery : The African and the Cretan continental slopes are weak backscatter zones. The slope off Cyrenaica promontory displays evidence of faulting that can be detetected over more than $20 \mathrm{~km}$ and attest of active deformation. The MR shows rather contrasted backscatter images. Its outer domain diplays zones of alternatively high and weak backscatter that are correlatable with sea floor features. Acoustic images reveals that a dense grid of lineaments are cross cutting most of the outer western domain. We interpret these as images of a conjugated faults network. North of this domain the MR exhibits various backscatter terrains. A southwestern province appears nearly homogenous acoustically, while northward of it exist several high backscatter patches that can easely be correlated with mud volcanoes field and mud flows (Volgin and Woodside, 1996).

Seismic reflection data : In the western survey area, the African continental slope appears as a thick wedge of sub horizontal seismic units, either tilted towards south or gently inclinated towards the north. These units may be distinguished to distance up to $30 \mathrm{~km}$ beneath the overriding deformed MR sediments wedge. Eastward the Herodotus abyssal plain contains a thick wedge of well stratified sediments that we interpret as distal, Pliocene and Quaternary, turbidites originating from the Nile deep sea fan. This cover rests over strong reflectors that we interpret as interbedded thick Messinian evaporites and clastics. Facing the Cyrenaica promontory, the frontal MR characterizes as a narrow belt of stacked thrusts and small piggy back basins with frontal sedimentary slumps. Eastward facing the abyssal plain, the MR outer zone appears as a progressively widening folded belt. The folds show a northeast southwest trend, and are often affected along strike by reverse faults and cut by conjugate set of faults. They constitute distinct structural belts disconnected by north-east south-west trending depressions interpreted as strike slip shear zones. Folds amplitude and wavelength progressively increase eastward, as a direct consequence of an increasing thickening of the recent sedimentary cover. Their spacing decrease northward as a probable consequence of increasing deformation. The central MR region is seen as an almost reflection free terrain, with the exception of narrow tectonic corridors (thrust and wrench zones) and mud manifestations. Further north thrust planes are observed either correlatable with backthrust-related reliefs or in contact with backstop seamounts (easter domain). Finally, the deep areas, north of the MR, contain a relatively thick recent cover above Messinian reflectors (Ryan et al 1973). We infer that this backstop, is progressively deforming and tilting northward. As a consequence of tectonic unstability, the post-Miocene cover migth be gliding northward using the underlying Messinian evaporites as a passive decollement level. Seimic data across Pliny trench and associated troughs do not show evidences of thick sediment infill nor of typical Messinian units. We therefore interpret the trench as a very young feature that has developed as a kind of active transform crustal boundary between a thin continental backstop and a thicker and more rigid pile of formerly tectonized units.

Integration of seismic data with detailed bathymetry and acoustic imagery allow to better asses the different deformational styles that characterize the Central and Eastern MR, and that are well expressed on its surface relief. The survey of the two areas reveals strong contrasts in structures west and east of $24^{\circ} 10 \mathrm{E}$ and east of $26^{\circ} \mathrm{E}$. Facing a tilted African margin segment, west of $24^{\circ} 10$, the MR is characterized by a complex pattern of surface and subbottom deformations ( stacked frontal thusts, internal thrusts, north-south lineaments, small mud cones, widespread mud flows and a major backthrusts). Its northern backstop is narrow and deep, only disconnected from the Cretan continental slope by narrow and shallow depressions.

By contrast, the central MR, east of $24^{\circ} \mathrm{E}$, displays a better organized structural pattern. The outer domain, facing the African margin, corresponds to a progressively eastward widening folded belt, cut by a set of conjugate transcurrent faults. To the north a series of 
thrusts disconnects this domain from a flat region cross-cutted by narrow tectonic corridors interpreted as surface expressions of deeply rooted thrusts and wrench lineaments. North of this zone extends a wide area characterized by mud volcanoe fields. Finally, east of $26^{\circ} \mathrm{E}$, the outer MR shows a series of fold belts disconnected one from the other by linear, en échelon, shear zones. This area is relayed northward by a wide province where huge quantities of mud seem to be progressively expelled, chiefly trhough transtensive faut zones. The backstop here comprises linear-block faulted blocks that reflect probable dominant strike slip activity.

We suggest that the specific deformational pattern of the western Central MR is best explained by the onset of collision between the Cyrenaica-Africa continental margin promontory, acting as an indenter, and the thinned edge of the Cretan margin. This would lead to increasing sedimentary deformation and probable crustal faulting, whatever the nature of the crust. In this geodynamic framework, the structural pattern of the Eastern MR would be chiefly the result of oblique convergence active on a thick pile of pre-Messinian, and eastward increasing evaporite-bearing Messinian, and Pliocene to Quaternary sediments.

\section{References}

CAMERLENGHI A., CITA M.B., HIEKE W. and RICCHIUTO T., 1992. Geological evidence for mud diapirism on the Mediterrranean Ridge accretionary complex. Earth and Planetary Science Letters, 109, 493-504.

CHAUMILLON E. and MASCLE J., 1997. From foreland to forearc domains : New multichannel seismic reflection survey of the Mediterranean ridge accretionary complex (Eastern Mediterranean). Marine Geology, 138, 237-259.

LIMONOV A.F., WOODSIDE J.M., CITA M.B. and IVANOV M.K., 1996. The Mediterranean Ridge and related Mud diapirims : a background. Marine Geology, 132, 719.

RYAN W.B.F., HSÜ K.J. and al., 1973a. "Initial Report of the Deep-Sea Drilling Project, Leg XIII, part1." Washington, (U.S. Governement Printing Office): 514 p.

VOLGIN A.V. and WOODSIDE J.M., 1996. Sidescan sonar images of mud volcanoes from the Mediterranean Ridge : possible causes of variations of backscatter intensity. Marine geology, 132, 39-53. 


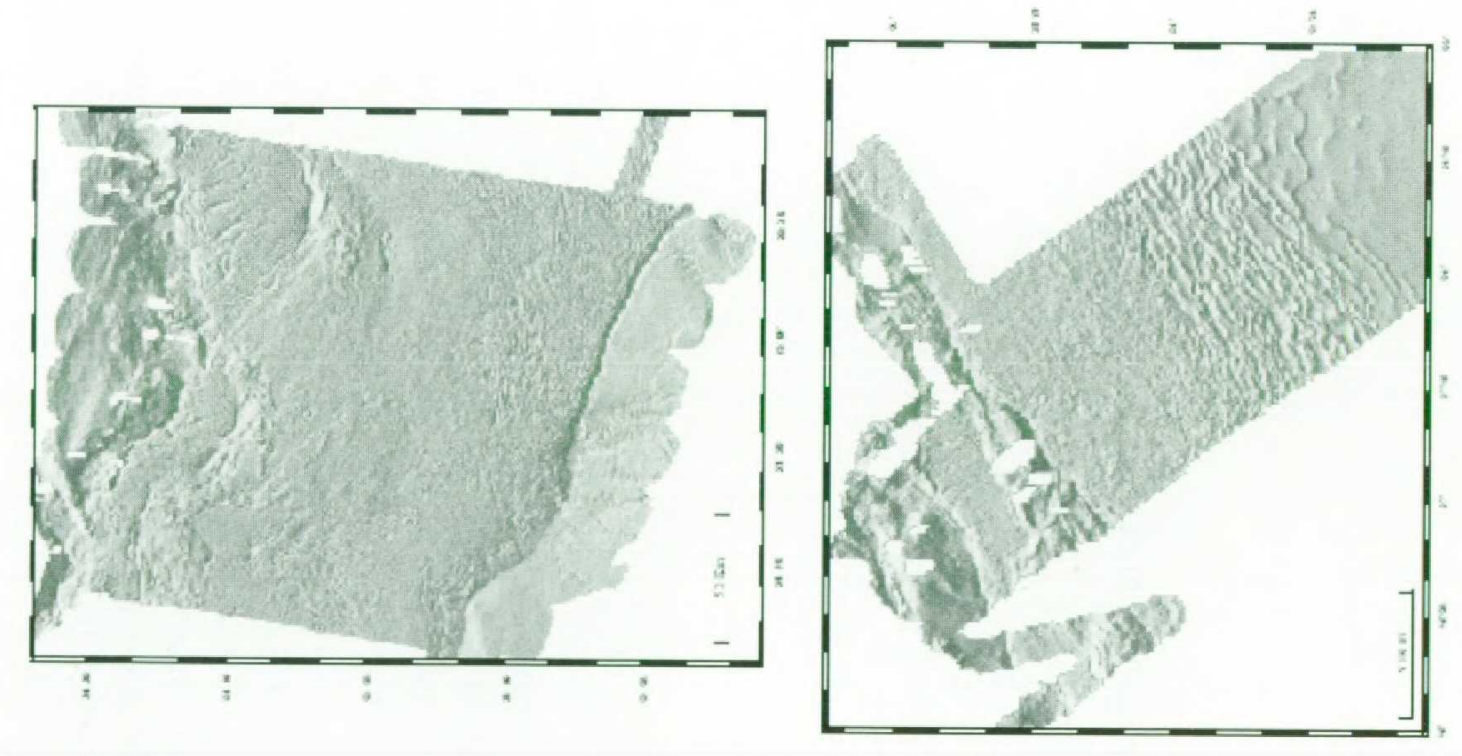

